\title{
ARTICLES/ARTÍCULOS/ARTICLES
}

\section{Repositioning security spaces of exclusion, exception, and integration in China-Southeast Asia borderlands}

\author{
Zhiding Hu, Victor Konrad
}

\begin{abstract}
Formerly localized, restricted border interaction between China and Southeast Asia has shifted to extensive cross-border engagement along regulated borders with a hierarchy of crossings and expansive borderlands. This expanded security system reveals rescaled and repositioned border security infrastructure and practice into a point and corridor system with vanguard crossings at Hekou, Mohan and Ruili. Fundamental shifts are concurrent focus on primary crossings and spatially extensive borderlands that encompass diminished attention to lesser crossings, beyond the border implementation of security checkpoints, mobile security, and compromise, to enable effective management of expansive borderlands. These borderlands mediate space and enable spatial reapportionment of security to accommodate greatly enhanced cross-border flows of people, goods, and information, thus shaping extensive spaces of exclusion and integration and focused places of exception.
\end{abstract}

Keywords: checkpoint strategy, emerging borderlands, point-corridor system, vanguard crossings

To gain understanding of changing security space at borders in globalization, it is necessary to comprehend borderlands evolution. Emerging borderlands between China and Southeast Asia provide an opportunity to examine a complex of economic, political, and security processes that have occurred rapidly over two decades as China and its neighbors have moved beyond closed borders, through establishment of borderland fundamentals of interaction and cross-border linkage, to borderlands that sustain institutionalized frameworks for cooperation and exchange (Fig- 
ure 1). Furthermore, the China-Southeast Asia interface is experiencing the full impact of globalization and localization forces as China develops its economic leadership in the region and as local populations work to reorient national priorities that impact their way of life. As documented in securitized borderlands elsewhere around the globe, "cross border societies remain in existence, resist, comply and adjust" (Deleixhe et al., 2019, p. 639). In this study, we focus on evolving security space in Yunnan province designed by Chinese central authorities and mediated by local and regional interests to facilitate yet control cross-border interaction. Understanding this altered and adjusted security space is a key to understanding spatial transition of China-Southeast Asia borderlands, and more generally, borderland transition in securitized space.

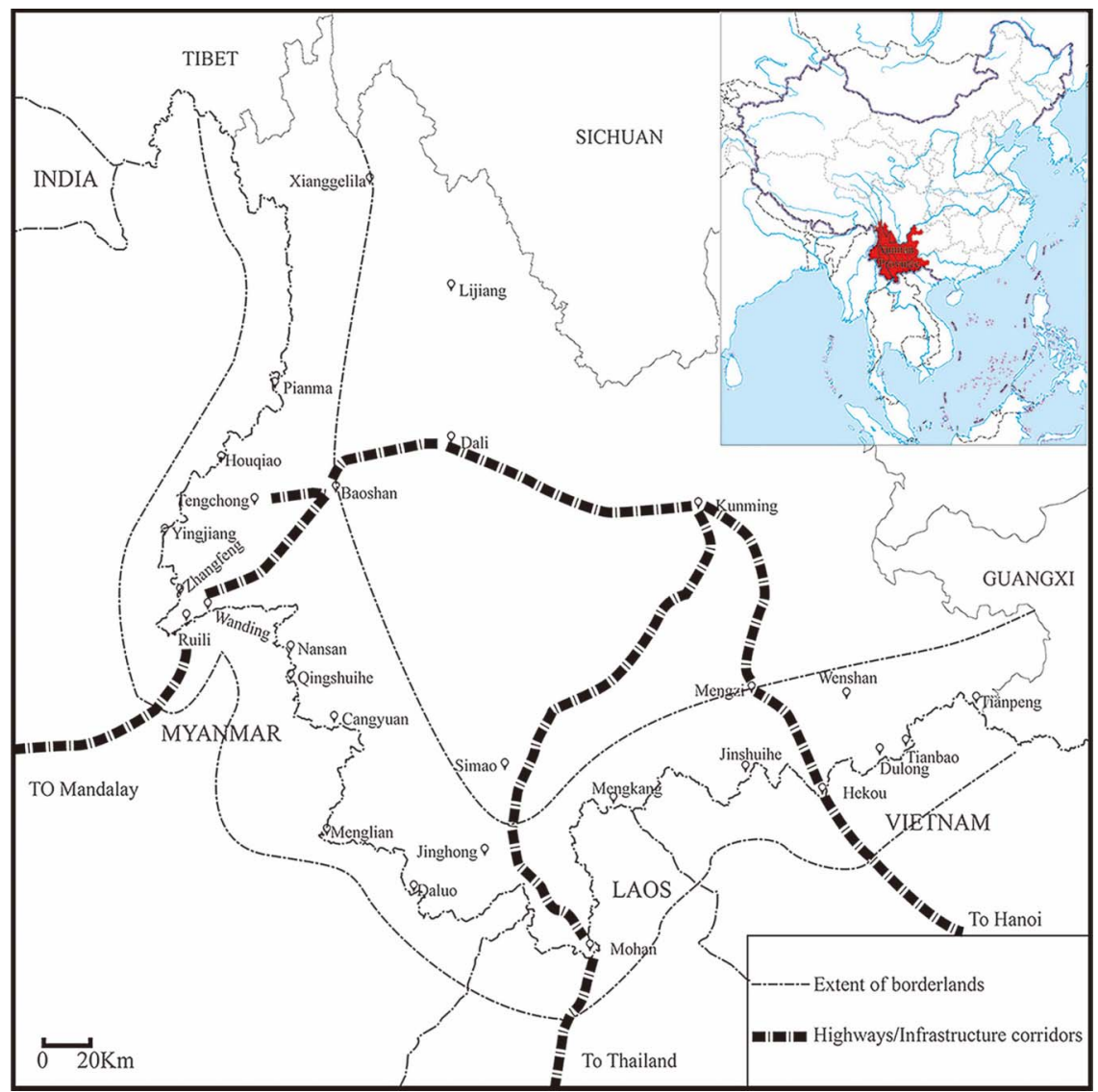

Figure 1 - Emerging Borderlands of China and Southeast Asia. This map by the authors locates the border crossings and borderlands features in the region. 
This article asks a central question: How is security space reconstituted from a closed borderline to a selectively permeable borderland in the evolving China-Southeast Asia frontier region? Several additional questions guide this inquiry. How did expanded security space evolve in the borderlands? What kind of security spaces emerged? How does the border security and cross-border interaction system work? What are the roles of border actors, and how have these changed? Overall, and fundamentally, the study articulates how borderlands are differentially shaped as secured places and spaces of exclusion, exception, and integration.

The article begins with an overview of China's southern borders and theoretical contexts for cross-border undertaking. Initial consideration is on what has been characterized as the Yunnan border crossing project (Masviriyakul, 2004). We argue that primary border crossings are key to understanding formation of borderland constructs. Accordingly, this study articulates the hierarchy of border crossings, arterial corridors, and spatial constructs that define emerging borderlands. This includes attention not only to tangible building blocks of borderlands security infrastructure but also to roles of agents such as central government, provincial authorities, and ethnic minorities in situating and sustaining borderlands security space. We argue that borderlands security space emergence and development involves coordinated scaling (hierarchical differentiation) of local to global flows, governance, and sustainability concerns. The analysis is based on hundreds of interviews throughout the borderlands, an extensive literature review, and six seasons of field investigation along the border. The perspective gained offers detailed consideration of how the border has been reconceptualized and reframed to accommodate both forces of globalization and localization within a government security and development agenda. In globalization, borders are loosened from their simple territorial conceptualization, and both are reduced and augmented in a more complex and mobile world (Konrad, 2015; Ptak et al., 2020). Yet, as illustrated in our study and along the border between China (Tibet) and Nepal, forces of localization sustain place and anchor tradition in this rapidly changing security context (Murton, 2019).

\section{Research design and methodology}

Exploring evolving borderlands has led us to examine Yunnan border regions and adjacent parts of Vietnam, Laos, and Myanmar. This empirical work, conducted over six years, includes detailed observation and documentation of regional infrastructure, processes and places, and interviews with hundreds of local residents, ethnic minorities, business people, gov- 
ernment representatives at local, regional, and national levels, military, and cross-border migrants in an effort to establish what Megoran (2017) terms a "border biography." The information gathered has been assessed and analyzed for several research projects of more focused perspective, but the data collected and the extensive record of exploration in the cross-border region, also yield substantiation of a massive shift in border region geography, and, significantly, theoretical advances in understanding evolving balances achieved in accomplishing cross-border integration and maintaining security.

First, it is necessary to become familiar with border crossings that, since opening in the 1990s, have expanded in number and capacity and changed in relative importance and functional complexity. Table 1 lists

Table 1 - Designated Ports of Entry, Yunnan, China Border with Vietnam, Laos and Myanmar

\begin{tabular}{lll}
\hline Port of Entry & Year of Research & Documentation \\
\hline Pianma & 2018 & semi-structured interviews (11) \\
Houqiao & 2015,2017 & questionnaires, semi-structured interviews (60) \\
Yingjiang & 2016 & questionnaires, semi-structured interviews (50) \\
Zhangfeng & 2016 & questionnaires, semi-structured interviews (50) \\
Ruili & $2015-2017$ & questionnaires, semi-structured interviews (220) \\
Wanding & $2015-2017$ & questionnaires, semi-structured interviews (80) \\
Nansan & 2014 & questionnaires, formal interviews (391) \\
Qingshuihe & 2014 & questionnaires, formal interviews (68) \\
Cangyuan & 2017 & questionnaires, formal interviews (120) \\
Menglian & 2015,2018 & questionnaires, semi-structured interviews (122) \\
Daluo & 2017 & semi-structured interviews (20) \\
Mohan & 2013,2016 & semi-structured interviews (35) \\
Mengkang & 2015 & semi-structured interviews (24) \\
Jinshuihe & 2014 & questionnaires, semi-structured interviews (89) \\
Hekou & 2014,2017 & questionnaires, semi-structured interviews (246) \\
Dulong & 2016 & semi-structured interviews (20) \\
Tianbao & 2017 & semi-structured interviews (15) \\
Tianpeng & 2015 & semi-structured interviews (20) \\
\hline
\end{tabular}

This table documents the formal ports of entry located along the border between Yunnan Province, China and Vietnam, Laos and Myanmar. During the years 2013-2018, the authors, assisted by graduate students from Yunnan Normal University, conducted semi-structured and formal interviews, and questionnaire surveys, at all of these ports of entry in order to develop a data base for exploring cross-border dynamics in the region. The data collected supports conclusions in this article as well as other specific studies on cross-border labour migration, trade and security.

Source: authors 
ports located on Figures 1 and 4 and identifies ports and nearby areas where the authors have conducted research, interviewed informants, and administered questionnaires. All ports listed were visited during at least one research season, whereas several major crossings have been evaluated over several years. Also during these research periods, authors recorded informal border crossings close to official ports. A combination of structured and semi-structured interviews was conducted during six consecutive field seasons by graduate students supervised by the authors and sanctioned by Yunnan Normal University according to ethical and security guidelines. Local and regional authorities were consulted according to standards established and monitored by the People's Republic of China. Interview questions pertained to why and how people crossed the border, their destinations, origins, routes, purpose, experiences, spatial knowledge, and personal data. Most of this information was utilized for specific studies of cross-border migration, special economic zones, and borderland dynamics (Ptak et al., 2020). Yet, the data reveal insights into types of security spaces and how they emerged, how the system works, and changing roles of border actors. To supplement data acquired from interviews and questionnaires, the authors engaged in extensive field observation within the region. Documentation of crossings also extended to use of border crossing yearbooks compiled for more than a decade for all Chinese ports of entry, as well as observations by other researchers working in the region.

\section{Literature review: Emerging borderlands as reconfigured security spaces}

Recently, we examined the emergence of Kokang, a territory occupied by Han Chinese in Myanmar, as a space between exception (separation, unconformity and even deprecation) and integration (linkage, association and even unity) (Hu \&Konrad, 2018). In the current article, we engage with spaces of exception (Agamben, 2005), exclusion (exteriority, not quite rejection but certainly seclusion) (Mela \& Toldo, 2019), and differentiated integration (Holzinger \& Schimmelfennig, 2012) in order to examine spatial dynamics of securing borders and facilitating emerging borderlands of interaction between Yunnan province in China and adjacent Vietnam, Laos, and Myanmar (Figure 1).The dynamic, evolving spatial processes of repositioning the border are fundamental to understanding the salient role of borders in globalization. In other global contexts, studies have documented emergence of new or expanded zones of border securitization as trade, migration, and other flows across borders have increased (Deleixhe 
et al., 2019). The establishment and thickening of the Schengen Zone around the European Union is well documented (Coman, 2019). Within this security space, or associated with it, are found special trade and security enclaves like Ceuta and Melilla adjacent to Morocco (Pallister-Wilkins, 2017) and the Green Zone in Cyprus (Casaglia, 2019). These spaces are either specifically or concurrently corridors, filters, barriers, and detention centers. In Africa, colonial legacy boundaries in the Sahel have enabled insecurity zones in areas remote from central government control and seen engagement of boundary parks and reserves as spaces of simultaneous exception, exclusion, and integration within an ecological framework of security (Ramutsindela, 2017). The Indigenous Reserve of Akwesasne/St. Regis on the US-Canada border, positioned between Quebec, Ontario, and New York, is a space of exception and exclusion, yet it facilitates crossborder interaction under Mohawk Nation scrutiny (Rouviere, 2019). In the United States, zones of border surveillance and regulation now extend one hundred miles beyond the border, and even further to encompass detention centers and US Homeland Security infrastructure. This extended security footprint appears "out of place" in the United States (Boyce, 2018) as it does elsewhere, yet it is emerging as the new normal, and it requires greater scrutiny and detailed assessment as bordering proliferates in globalization (Konrad \& Brunet-Jailly, 2019). Most studies previously noted focus on the nature and uniqueness of security spaces but do not necessarily trace their evolution or examine the interplay of spaces of exception, exclusion, and integration as a dynamic and chart the "security-scapes" (Appadurai, 1996) that emerge.

Rapidly evolving borderlands of China and Southeast Asia present an opportunity to accomplish such broader assessment because this is an extensive cross-border region, with multiple and comparable border security contexts, linked to clearly established processes of infrastructure development and security management. Transformed from a frontier to an economic "bridgehead," Yunnan province materialized as a new state of development in China (Su, 2013). Yunnan thrusts significantly into Southeast Asia in order to provide effective access for China into bordering countries, their immediate neighbors Thailand and Cambodia, and India, Bangladesh, Singapore, Malaysia, and Indonesia (Figure 1). In essence, the province is identified as China's gateway to southern Asia (Su, 2016). Ultimately, Yunnan has been repositioned in China and in Southeast Asia. The province's extensive border with Southeast Asia is viewed now as an asset and a zone of linkage and transition to the south.

In Yunnan, interplay of increased cross-border interactions, at various scales and in specific locales, has set the stage for emerging borderlands (Sturgeon, 2013b). Cross-border cooperation has become intertwined with 
region-making (Chen, 2018). This rescaled and multiscalar regionalization has been explored to explain regional and urban development dynamics (Chen, 2018), but the research also calls for alignment with border studies theory and approaches and more attention to rearticulation of security space. Only recently, have researchers in this region addressed border interaction with China (Lagerqvist, 2013). International land boundaries are not in dispute here, but territorial entitlement and sense of ownership across the border prevail, particularly among Chinese occupants of borderlands who recognize historical evidence of Chinese construction in Lao Cai, Vietnam, for example, or claim kinship with Han residents of Kokang, now in adjacent Myanmar (Hu \& Konrad, 2018). The border has never been closed completely, and it is difficult for governments on both sides to close the border to formal and informal exchanges. These spaces are remote border areas far from administrative and supply centers, particularly in Laos and Myanmar. Here, border area residents will buy and sell across the border to sustain themselves. China has recognized the growth potential of cross-boundary exchange, and offsets from this trade may help increase the standard of living for residents in Yunnan borderlands. In some circumstances, cross-border trade promotes economic development in border regions. Although national security remains less of an imperative in these borderlands than, for example, China's borders with some of its western and northern neighbors, an endemic drug problem has resulted in a regime of strict border security to interdict drugs at the same time that other flows - rubber, sugar cane, livestock - are enabled and promoted (Baird \& Vue, 2017; Su, 2015; Turner et al., 2015). Overall, the Chinese government's aims at national, provincial, and local levels are to coordinate trade and development, enhance security, and lessen regulation. The sanctioned movement of goods and people across borders now epitomizes a new order in border relations on China's perimeter (Summers, 2013). The goal in this article is to link insights about border security space with economic, urban, and cultural dynamics in these borderlands within a framework to help explain how these spaces of exception, exclusion, and integration emerge.

\section{Conceptual approach}

A new and expanded role for the border zone, with the Greater Mekong Region as its apex (Chen, 2018), requires a multilayered and flexible approach to border security to at once maintain integrity of the border and Chinese territory and enable and adjust to rapidly evolving and increasing cross-border flows. Accordingly, security is approached as a multifaceted 
project ranging from zero tolerance on drugs at the border to acceptance of unregulated exchange of common consumer items and displaying different security goals and strategies at local, regional, and national scales. Spaces of exception, exclusion, and integration emerge within borderlands according to a spatial order based on mediation of governance, flows, cultural tradition, and security imperatives. The approach in China has been flexible and dependent on the circumstances of 14 bilateral border relationships. Border security space for China usually encompasses a border security zone of variable extent and intensity within China and a negotiated presence in neighboring countries, such as surveillance zones in Nepal (Murton, 2019) or special trade exclaves in Laos (Nyiri, 2012). Formerly marginalized, these border spaces have increasingly acquired more central geo-economic and geopolitical importance, and the security spaces have the most profound impact at a regional scale (Su, 2016, p. 184). When there is conflict, as demonstrated recently in Kokang along the Myanmar border, the border security zone is locked down and cross-border movements are restricted (Hu \& Konrad, 2018). In the rapidly evolving borderlands of China and Southeast Asia, multiscalar expression of security challenges appears to engage with economic, political, social and cultural concerns in a relational motion of policy adjustments and innovations (Ptak et al., 2020).

We offer a conceptualization of how this works to reinterpret and redeploy boundaries in borderlands by Chinese authorities as well as borderlands residents. First, China's central government in coordination with Yunnan province prioritized strategic "high-level" ports by linking them to Kunming with expressways, defining their priority with institutional arrangements, and supporting their growth with large construction projects (Figures 1, 2, 4, 6). In order to promote economic development and cooperation, China and its neighbors established border economic cooperation zones at high-level ports (Chen, 2018). These zones are now located at three primary crossing points-Ruili, Mohan, and Hekou-and nearing completion at Houqiao crossing on the proposed arterial across Mynamar to India. Also, to promote circulation of people and goods in these formally "bounded" areas, and adjacent borderlands, all neighboring countries, and particularly China, adjusted the boundary effect by strengthening the mediation effect of the international boundary and by weakening the shielding effect of this border. But, by weakening the shielding effect, security became compromised. This compromise of the territorial order is a fundamental shift in the borderlands spatial reconfiguration. A line becomes a space, and this space assumes content differentiated from space beyond the now formalized borderlands, because it is contained by another line. China, and to a lesser degree its immedi- 
ate southern neighbors, established alternative security borders at a distance inside the borderlands (Figure 2). For China, these security borders sometimes number two or more lines of security checkpoints within 50 $\mathrm{km}$ of the international border. A core zone of the borderlands at the international boundary is easily and regularly traversed by local residents, and the international boundary has become more symbolic for them. The real control for borderland residents, from both sides of the international boundary, occurs at alternative boundaries where security checkpoints may be crossed only by persons authorized to enter or leave borderlands China (Figures 2, 3). The significance of this spatial reconfiguration of security space is evident at once in the simplicity of the spatial alteration and in the considerable impact that spatial change wields in regional development, mobility, interaction, stability, and, ultimately, security.

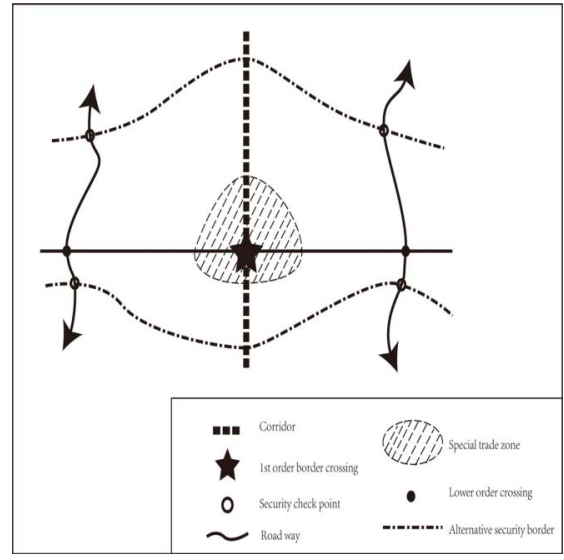

Figure 2 - Conceptualization of Borderlands Security Strategy. This diagram by the authors illustrates how border security is evolving into a spatially extensive borderlands security system of regulated crossings, check points, corridors, and border places.

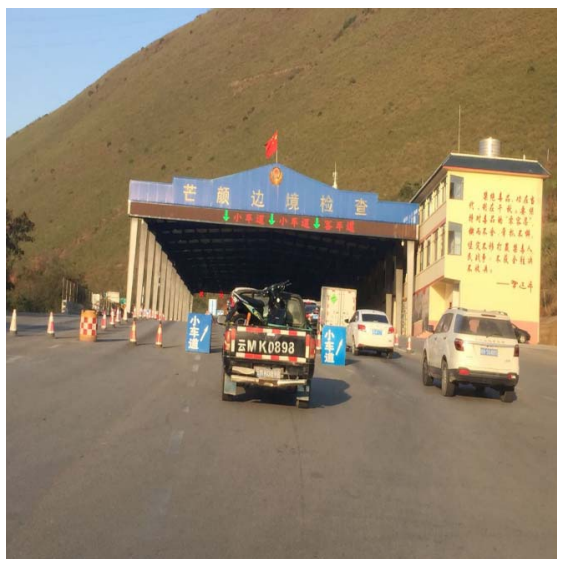

Figure 3 - Security Checkpoint on Expressway between Mangshi and Baoshan, China. This photo by Zhiding Hu emphasizes the implementation of strict controls at a distance from the border on major arterial transportation routes. The photo was taken on June 11, 2017.

\section{The changing role of security in borderland places and spaces: From common edges to scaled and differentiated crossings}

Clearly evident from the research is an emerging hierarchy of border crossings and corridors that rapidly form a framework and template for further borderlands articulation and development. Within this framework, the 
border, border places, and border spaces all become rescaled. Although this process of evolving borderlands is extensive and engages most places and spaces in the vast border region stretching more than $2000 \mathrm{~km}$, three arterial corridors emanating from Kunming play the major role in connecting, integrating and shaping the China-Southeast Asia borderlands. These three corridors each connect Kunming, center of the emerging borderlands, to Vietnam, Laos (and Thailand and Cambodia), and Myanmar. Figures 1 and 4 illustrate centrality of Kunming in this emerging system of places, establishment and enhancement of major border crossings with border economic and security zones, and elevated strategic importance of intermediate points along these corridors to Southeast Asia.

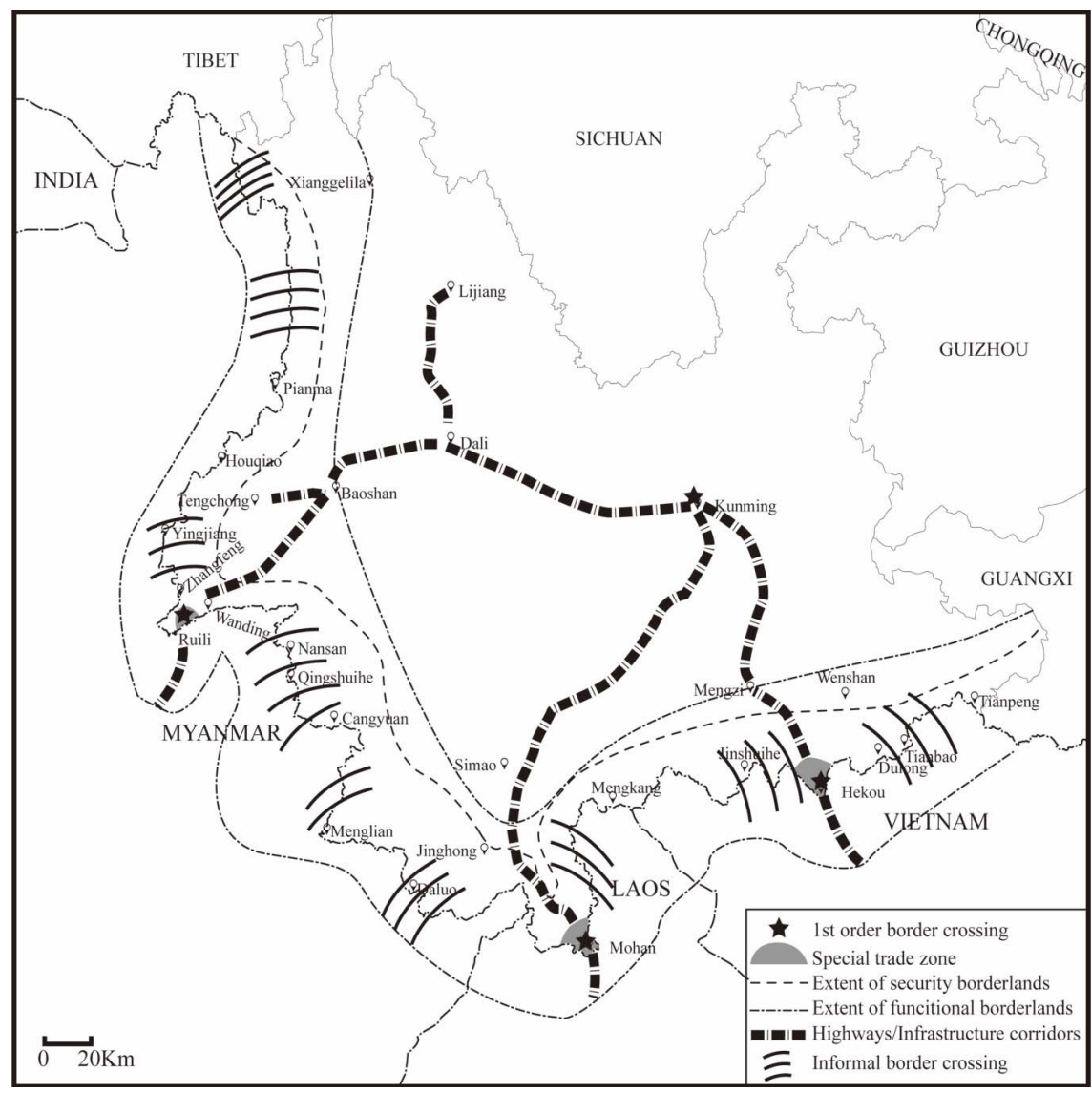

Figure 4 - Expansive Borderlands. This map, compiled by the authors, illustrates the features of the evolved border crossing system of checkpoints, special economic zones, corridors, and borderlands places in the cross-border region. 


\section{Hekou-Lao Cai}

A significant changing role of place is transformation of edge places into crossing places in a hierarchy of enhanced border crossings (Fox, 2009). Some edge places, the vanguard border cities, have changed most dramatically in size, number and alteration of functions, crossing enhancements, and overall settlement viability (Teng et al., 2017). One vanguard border city, Hekou, located approximately $400 \mathrm{~km}$ southeast of Kunming, is recently accessible from the metropolitan hub by a four-lane highway. About $20 \mathrm{~km}$ from the border, there is a military checkpoint, and there is another security check at the formal perimeter around the bustling border city of Hekou with its separate auto and people crossings to Lao Cai, Vietnam, and Hanoi beyond. Hekou epitomizes at once a space of exclusion and exception and a place of enhanced integration. As illustrated in the following discussion, security space is expanded, extended to specific points and zones within the borderlands by national authorities engaging with local actors, and differentiated to shape a multiscalar security complex focused on Hekou.

Hekou occupies a security zone where all persons and goods are checked before they enter or leave the perimeter. Inspection is managed by Chinese military to control and restrict crossing to the "urban island" of Hekou within a vast, underpopulated tropical jungle. Wenshan (Tianbo) crossing lies a challenging five-hour drive east, and Jinshuihe crossing is situated an equally difficult two-hour drive west along narrow mountain roads. Outside Jinshuihe, a Chinese military facility commands access to the border zone. Approximately $60 \mathrm{~km}$ north, a "border inspection" facility at Jinping commands a cross-road town in Hani ethnic territory. This inspection facility allows strategic control of traffic within the expanding border zone, although it cannot control access across the border by local trails. Consequently, as reported by local inhabitants, informal crossing still occurs, but this type of crossing is becoming less common and is now restricted to very remote stretches along the border. The border region extends to Mengzi where borderlands functions related to transportation, utilities, and security management are concentrated.

Access to and from Hekou requires electronic checks of identity documents. This insures that local Vietnamese may not travel farther into China than Hekou, whereas authorized travelers including business and transport personnel have documentation to pass. Trucks and cars crossing between Vietnam and China must now use the recently constructed highway bridge where inspection is rapid and thorough, with scanners, computers, and traffic control. Adjacent to the crossing is the Beishan Development Area, which provides border functions such as brokerage and truck repair. Scaled down from this facility and crossing process is the tra- 
ditional formal crossing between the centers of Hekou and Lao Cai across the Red River. This local crossing is now restricted to pedestrian traffic although substantial trade still occurs here. Before the highway bridge was completed, a massive rush of thousands of Vietnamese crossed daily in an assortment of vehicles and on foot. Today, the crossing ritual still begins precisely at eight o' clock in the morning, but film records confirm it is more subdued and managed than before. Lines for people with and without goods form in Lao Cai before the barrier is lifted. The quickest Vietnamese across the border are assured rapid access to begin the day of domestic work, vending, or other sanctioned activity in Hekou. After immigration and customs clearance, waiting taxis and motorbikes take Vietnamese to work. Vendors move carts and bicycles to their spots around the city. Most entrants carry local identity documents that are not machine readable and, consequently, may not be used to leave Hekou security zone (Figure 5). One of the domestic workers interviewed showed us her "passport," which contained multiple pages of entry and exit stamps, each recording a day spent working in Hekou. Daily registration takes place in a newly renovated and air-conditioned facility that also boasts a large duty-free shop that caters mainly to returning Chinese. Hekou is now a place increasingly connected with other places in China and in Vietnam as homeowners rent their houses to Vietnamese and Chinese businessmen while they live elsewhere in the community or work in eastern China.

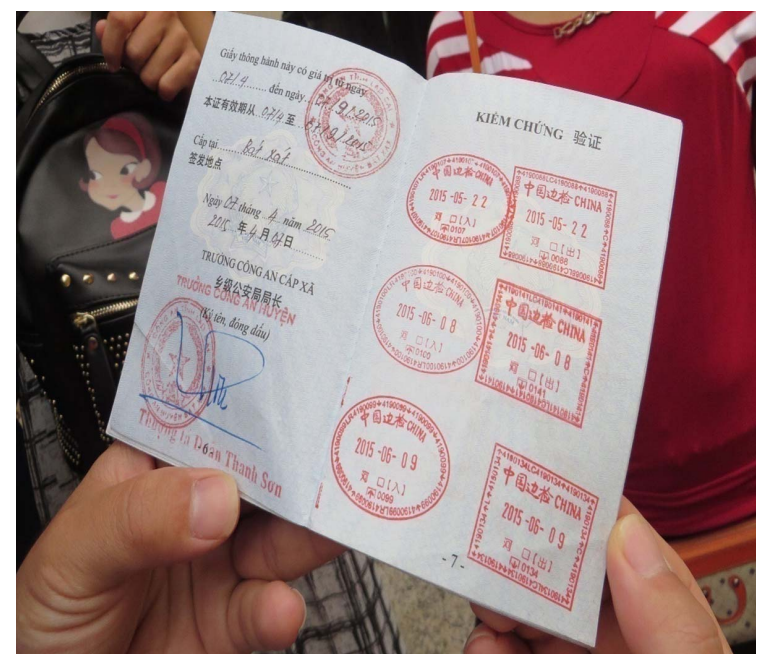

Figure 5 - Identity Document for Vietnamese Worker in Hekou. This picture reveals the daily record of border crossing required by Vietnamese workers in Hekou. The document is good for entry and work in Hekou, but it may not be used for travel into China beyond the border city. Photo by Zhiding Hu, June 10, 2016. 
Across the border, Lao Cai serves as a bedroom community for the workforce that migrates daily to Hekou. Lao Cai features a growing number of the gambling facilities and clubs now outlawed in adjacent China. Also evident are services catering to cross-border traffic of local and long-distance nature, including auto repair, brokerage, accommodation, and restaurants. The highway from Lao Cai to Hanoi has seen significant upgrades, particularly since the completion of the expressway from Kunming to Hekou. It is now possible to travel between Hanoi and Kunming in one day. Unlike in Hekou, security in Lao Cai remains largely focused at the border.

\section{Mohan-Boden}

Mohan is the main crossing point from China to Laos and subsequently to Thailand, as one travels directly south from Kunming on the recently completed expressway through Jinhong to the border. Until 2016, only one crowded road provided access from Jinhong to Laos, with long lines of trucks waiting to cross the border, and then proceed slowly to Chiang Rai in Thailand. Current infrastructure development on both sides of the border is, however, expanding and driven by Chinese interests. Local officials confirm the Laotian government has rented space at Boden to Chinese business interests for 99 years. By locating on the Laotian side, Chinese businessmen exclude Chinese diplomatic and military controls at the border. Accordingly, many Chinese companies are investing in this new approach to cross-border integration. Astride this border, the gray stone of the Chinese facility contrasts in architectural style and color with the golden Laotian portal, which resembles a Buddhist temple. Yet, this contrast is deceiving because the symbolic differentiation at the boundary masks the crossing in a border region with considerable cultural continuity and economic integration. In this upper Mekong region, border security space has been reconstituted as both an expanded borderlands approach featuring numerous security checkpoints at regular intervals on roads to the border and an emphasis on security at the borderline. The primary border actor, China's central government, prioritizes drug interdiction and "off-shoring" gambling. Yet, ethnic Dai prominent in agriculture and trade in the international region lead and collaborate in cross-border integration efforts and support security normalization and streamlining through corridors and in special trade zones.

Similar to the Sino-Vietnamese border region, the Mekong borderland is connected to Kunming by expressway. A large security checkpoint is situated on the highway $20 \mathrm{~km}$ north of Jinhong. South from Jinghong, the highway separates and continues to several state border crossings 
into Laos and Myanmar. Dalou is the gateway to Myanmar in this region. Once a busy border town, Dalou boasted a mix of legitimate and illicit businesses and tourist attractions, but, due to Chinese government crackdown on illegal practices, Dalou lost most of its border business to adjacent Mongla in Myanmar. The Mohan crossing to Laos is favored with the special trade and security zone although other state and local crossings in this heavily populated central southern border region also carry substantial traffic to and from Thailand and adjacent Myanmar and Laos. Throughout the borderland region, and particularly at key nodes in the road system, checkpoints are found to accomplish security work beyond the border. Approaches to Dalou and other crossings to Myanmar have multiple, consecutive checkpoints.

Jinghong, center of Dai culture in Xishuangbanna, is a sprawling urban area of over one million inhabitants and serves as south-central service center for Yunnan province and the cross-border region. The airport provides not only regularly scheduled service to Kunming but also recently international service to Thailand and other locations in Southeast Asia. Jinhong is linked directly to several state and local crossings and is terminus of cross-border boat traffic on the Mekong. Throughout Jinghong, visible evidence of cross-border economy, society, and culture abound in architecture, symbolic statuary, street decoration, and Buddhist religious sites. Less overt are indications of border security and control evident in patrols and checkpoints for drugs and illegal migrants.

\section{Ruili-Muse and the western borderlands}

Ruili is the center of borderlands that stretch from Tengchong near the foothills of the Himalaya south to Kokang. In these fertile valleys, Han and ethnic Dai and Jingpo occupy the expansive borderlands. There are numerous border crossings but only a few national crossings (Figure 4). Since 2015, Chinese territory adjacent to Kokang remains a restricted security zone where the Chinese military controls all movement into and out of the 20-30 km wide border zone (Hu \& Konrad, 2018). In contrast, the national crossing at historic Wanding, utilized by the allies in World War II against Japanese invasion of Burma, is open to tourists from China and abroad. Wanding Border Port Culture Park celebrates the interface of China and Myanmar and the ethnic minorities who occupy this region. The region is an extensive agricultural and industrial area long occupied by Han Chinese at the mountainous frontier of Chinese expansion and trade. Security space embraces restricted zones under military control in Kokang and north along the Kachin frontier, special security, trade zones, and expedited crossings at Wanding, Jiegao, and Houqiao, interior check- 
points along major thoroughfares into the border region, and relatively casual surveillance at local crossings throughout the borderlands.

One highway and infrastructure corridor, completed in 2017, leads to Dehong. The high-speed railway, and other aspects of infrastructure are under construction. Adjacent to the north is rural Longchuan County where Han farmers and entrepreneurs from other parts of China engage in small business including cross-border trade. Tengchong County, junction of Han civilization and the Lisu mountain tribe frontier, was a southwestern hub of the Silk Road established in 206 BCE. Recently, the small yet rapidly expanding city gained an airport at Tuofeng in 2009 and was connected to Baoshan by expressway in 2016. Security checkpoints are both fixed and mobile in these borderlands, illustrating the rapidly changing nature of security requirements as infrastructure evolves constantly, cross-border trading patterns shift, and border relations change with autonomous minorities across the boundary in Myanmar.

The northwestern route into the China-Myanmar border region, Houqiao Port, near Tengchong, was opened to Myanmar in 2003. In 2017, despite limited cross-border traffic, an international market and duty-free facility were completed, reflecting China's "build it and they will come" policy of border crossing development. Also found along the border are small, local crossings and, beyond these, informal crossings where people feel confident in merely jumping the border at will. This is tolerated by both Chinese and Myanmar officials because interior checkpoints seal immediate borderlands. About $50 \mathrm{~km}$ into China from the "Tengchong border" lies the additional frontier checkpoint at Feng Ping. Like other interior checkpoints, this military post serves to secure movement in the borderlands. Although cross-border trade in this area is dominated by importation and manufacture of hardwood from Myanmar, shipments are monitored to ensure that illegal substances and manufactures are not allowed. Isolated in the far west is Pianma port where most cross-border traffic is local and no interior checkpoint is evident, or, apparently warranted, although there is evidence of disassembled, mobile checkpoints. From Pianma north to the junction of Myanmar, Tibet, and Yunnan, mountain ranges dominate, border crossing is localized, and security is casual.

The southern expressway prong crosses into Myanmar near Ruili, the major entry point into Myanmar from China. Ruili is a modern sprawling and affluent city with wide boulevards and substantial suburban expansion fueled by growing trade with Myanmar. The focal point is the special trade zone of Jiegao (Figure 6). Here is an entry and exit checkpoint before one actually arrives at the pedestrian and auto crossings to Myanmar at Ruili/Muse. The special trade zone is dominated by Chinese merchants engaged in jade trade whereas other cross-border trade, particularly hard- 


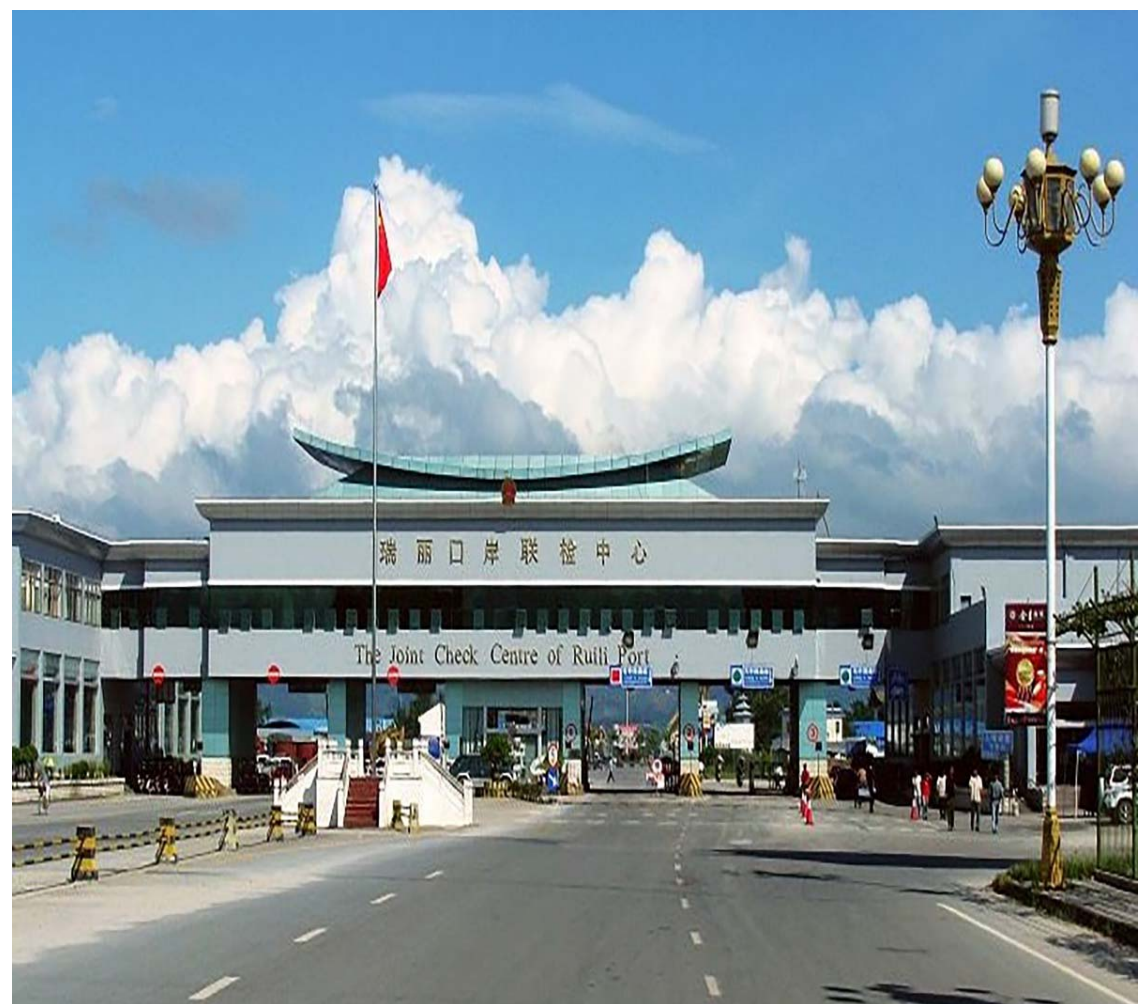

Figure 6 - Jiego Trade Zone Entrance, Ruili, China. This photo shows the imposing gateway into the special trade zone in Ruili. Burmese allowed to work in Riuli's trade zone may not venture outside the zone. Chinese traffic into the trade zone is regulated at this gate as well. Photo by Zhiding Hu, September 12,2015

wood, is found both in the zone and beyond it in the burgeoning city. In the trade zone, the jade section hugs the border and conducts a brisk and competitive trade, mainly to Chinese from other parts of the country. Also here, low order goods, like cigarettes, candy, and other consumer goods, and high order goods, like drugs, are sold "through the fence." According to informants, the murky border "where Burma dissolves into China" is found in the trade zone and in more remote rural areas away from Ruili.

\section{Changing role of security}

As China pursues the "Belt and Road" initiative, preeminence of the corridor from Kunming to Ruili, and then from Muse through Mandalay and Yangon to the Indian Ocean, becomes increasingly important. Trans- 
mission lines serving hydroelectric dams, petroleum and gas pipelines, and other major infrastructure developments have been situated in this corridor. It remains for Myanmar's road connections to be raised to the two-lane international standard and for the critical section from Muse to Mandalay to be upgraded. The Greater Mekong Subregion Highway from Muse through Lashio to Thbaw remains a transportation bottleneck for traffic approaching 1500 trucks per day. Suggestions to restrict Myanmar Highway 1 to cars and buses only and develop ASEAN Highway 14 for trucks only have yet to be implemented (Ksoll \& Quarmby, 2013). Furthermore, Muse, in sharp contrast to Ruili, remains relatively underdeveloped with extensive poverty, a migrant glut from other parts of Myanmar, and a surfeit of gambling, drugs, and prostitution. Although border security in the vanguard crossings remains focused on the border to restrict unwanted people and goods from entering China, the immediate border region gains significantly from redefining border security spaces as exclusionary zones and places of exception, and moving security checkpoints beyond the border at strategic places in the borderlands.

Edge places down the hierarchy of border crossings have experienced less change. For example, whereas Hekou and Jinshuihe are both "national" crossings between China and Vietnam, the former has seen extensive transformation whereas the latter remains a relatively unaltered crossing point where cross-border transfer of a load of bananas is a highlight of border activity. At Jinshuie and other remote places on the China-Vietnam border, "upland trading-scapes" with traditional exchange characteristics of ethnic minorities still prevail (Turner et al., 2015). In these areas of extensive informal crossing and trade of agricultural and low order goods, border security is limited and subdued.

Coincident with the changing role of edge places is the transformation of border administrative spaces, particularly counties, into focal areas for development of border trade and management of security at checkpoints (Baird \& Li, 2017). This model of decentralized development originated early in the establishment of formalized cross-border trade and it prevails in concert with security strategies to alter border territory and specific border places.

Revealing is the transformation of interior, intermediary places along corridors from Kunming to the vanguard border cities of Ruili, Jinghong, and Hekou. These interior cities-Baoshan and Mengzi-are prefecture level centers located on the direct line between Kunming and vanguard cities. With the advent of corridor construction and completion of highway and other infrastructure enhancements, these places have become better connected to Kunming and, crucially, better connected to the border. Consequently, they emerge as major linking places in expanded border- 
lands and have experienced substantial recent growth and modernization. Baoshan, for example, recognized as a link on trade routes for millennia, has emerged as doorway to the rapid routes to Myanmar via Tengchong and Ruili and a strategic security checkpoint. Baoshan and Mengzi mark the final transition from borderlands and border security.

Once quiet crossroads, or places on ancient trade routes within ethnic minority territories near the border (Zhou, 2012), strategic locations have become key security checkpoints in a system of border management "beyond the border." These security checkpoints within the expanding borderlands enable efficient control of vehicular traffic to and from minor crossings and, to a degree, control of informal crossing that still occurs.

Vanguard crossings stand to become even more significant places in the border crossing system. These rapidly expanding sites of exchange and cross-border movement demand new approaches to expedite crossing and sustain security. Here are found the emergent special border economic zones with graded security (Figures 4 and 6). Hekou, Mohan, and Ruili all exhibit such developments, and these facilities are under construction at Houqaio near Tengchong. As cross-border traffic increases and the border crossing system becomes more established, these special economic zones and facilities such as duty-free shops and "international" markets likely will grow in concert with security enhancements. Already evident at Hekou, Ruili, and Jinghong, cities designated and evolved as gateways on the corridors are becoming destinations for Chinese from across the country, both as tourists and as residents. International tourism remains limited but is increasing. Connections among places at the top of the crossing hierarchy-Hekou, Mohan, Ruili-are national and increasingly binational and global, whereas smaller localities in the borderlands remain isolated. Security approaches to this variegated and hierarchical border crossing complex reflect a diversity and sensitivity to local as well as national security imperatives and ethnic realities.

Ethnic minorities predominate along the border in segmented crossborder territories and sustain cross-border linkages now sanctioned and encouraged by authorities (Wang et al., 2013). Cross-border connections, sustained even in times of closed borders, flourish when borders are loosened. Yet, more instructive than this predictable result are the patterns of collaboration in security management among ethnic minorities, and between ethnic minorities and the Han majority as borders are opened. "Border strategies" of secured trade mobility among Dai (Tai Lue) on the China-Laos frontier rely on sustained connection and adherence with Han authority and approach as "part of a long-applied governing pattern of "experimentation under hierarchy" on the Sino-Lao frontier" (Diana, 2013, p. 25). 


\section{Scaling local to global flows and security: Emerging geopolitics}

Borderlands of China and Southeast Asia exhibit defined scalar thresholds-local, regional, provincial, national, and global-and multiscalar production within emerging borderlands (Ptak \& Hommel, 2016). Whereas the anchor of locality holds strong and is sustained by ethnic minority culture and status, local borderland economies and isolation, borderland localities are defining themselves as ethnic minority regions along the border. Here are found local flows of goods, peoples, and information now sanctioned and supported by an open-border policy. Beyond this strong local and micro-regional identity and system of flows, the threshold to provincial connections and authorities, and cross-border interactions, remains more ambiguous (Freeman \& Thompson, 2011). Yunnan provincial authority is actually more present than it appears in the borderlands by virtue of growing metropolitan dominance of Kunming in southern China. Although Kunming is a long way from the border, this rapidly growing hub influences the emerging character and connectivity of borderlands (Ptak et al., 2020). In the case of Mynamar, the greater autonomy of Burmese borderland "states" contributed to borderlands interaction well before the border was opened. Yet, recent extension of federal authority to peripheral regions suggests that a new order of borderlands interaction may be emerging, with an emphasis on greater engagement of central government in borderlands security management. Thresholds to national and global scales within the borderlands are more evident and well signed. National crossings are readily identified by national symbolic images and huge flat screens offering videos of Chinese state messages regarding territorial sovereignty, cultural awareness, infrastructure advances, and economic goals. These symbols, although more subdued and less technologically advanced, are found at provincial and local crossings as well. English signage is the cue to global thresholds. The sudden appearance of English signage at or near the vanguard crossings is usually associated with an international trade space or directions and information for non-Chinese. National and global flows of people, goods, and services are still comparatively new to the borderlands. These flows, and the security measures designed to control them, are highly concentrated in three arterial corridors and places and spaces associated with these corridors. Chinese armed forces are characteristically situated in bases nearby, and their presence and participation in security work is evident at strategic checkpoints in both populated and underpopulated spaces in borderlands.

Within borderlands, security works increasingly with a "beyond the border" strategy which is overt and often subtler. Kunming is an acces- 
sible international metropolis, but as hub and flow-through center of the borderlands transportation and communication system, it is a securitized space. This is increasingly the case for the international airport and the central train station that experienced a terrorist attack several years ago. Security checkpoints also are found at strategic locations in the borderlands secondary road network. The security forces recognize the need for efficient control of growing, extensive, and accessible borderland territory by policing not only the border but also extended borderlands space. The interior line of checkpoints defines an edge of borderlands that is misleading because functional borderlands extend beyond this security perimeter to intermediary cities and the borderlands hub. Also, informal exchange and crossings among border locality residents are tolerated and scrutinized minimally. Observations at or near smaller, local crossings laying in Long Choan County, and Jinshuihe on the Vietnam border, suggest that border security has a light touch with regard to informal crossing by local populations and their exchange of low order goods. Formal business and travel across the border is treated, however, with formal identity verification and required levies for goods. In this international exchange arena, security now demands machine readable documentation for both people and goods.

\section{Conclusions}

For three decades, China has accelerated trade and interaction across its boundaries. Initiatives like "Belt and Road" continue to emphasize that, while China moves to develop more extensive relationships with its neighbors and global partners, cross-border linkages aim to sustain territorial and border integrity. China's territorial vision has moved beyond the historical metaphor of the "wall" to define edges and limits yet articulate borderlands creation that combines cross-border engagement with territorial integrity. In these new borderlands, extensive infrastructure enhancement, economic development, cultural viability, and security positioning all play roles in rescaling and rearticulating border space, shaping coexistent spaces of exception and exclusion, and integration.

China's borderlands with Myanmar, Laos, and Vietnam, have been, until recently, remote and underdeveloped in multiscalar cross-border connections and flows. Change has been rapid and resulted in emergence of specific border constructs and visible and measurable evolution of a borderlands regime. Forces and constructs evident, and their interrelationship and sequencing, illustrate an evolving "security-scape." In a China- 
Southeast Asian context, top-down influences and articulation by central governments, and particularly by Beijing, are catalysts for borderlands security. Yet, whereas central governments often align and form the border security regime and establish controls, local and provincial governments and powerful local agents lead the move toward crossing the border. Also, bottom-up initiative, resistance, and compliance, mainly by ethnic minorities, shape the evolving border crossing and security space. There are, then, multiple Chinas, rather than a central Chinese monolith at work in fashioning the borderlands. Aligned with this evolution of borderlands, and the immense changes accompanying it, is an approach to border security that is decidedly "beyond the border" in character and intent.

This article has examined the security spatialization process with a focus on vanguard crossings at Hekou, Mohan, and Ruili. A major conclusion that challenges the prevailing notion that borderlands are largely a transition or interaction zone between two nation-states is that borderlands evolve with discernable structure, spatial complexity, and place differentiation. When borderlands emerge, space and place are challenged and a new order of relationships evolves. As suggested in this study, some places are invested with new status, power, complexity, and viability, whereas others may become less important in a new "borderlands hierarchy." Spaces such as corridors and special trade zones bolster this new order. Vanguard crossings lead the crossing regime and cap the hierarchy of crossing places. An interior "border place" predominates as a hub in the emerging borderlands system of places. And, in-between the hub and border, are discernable edges of successive security spaces and functional borderlands.

Another conclusion supports the growing understanding that borders and borderlands are always in relational motion. This is certainly apparent in the emergence pattern outlined in this article. Places and spaces change within expanding borderlands and in relation to the changing nature and positioning of the border. Actually, multiple and differentiated borders emerge at the state boundary where locals and ethnic minorities have different borders than other Chinese or foreigners. In the borderlands, there are other borders at checkpoints. A primary border has emerged at Kunming's international access points. Furthermore, this motion and change appears to be continual with no finished border or borderlands in sight as borders and security are repositioned and rescaled. Even the goal of efficient, integrated borderlands remains elusive, because it is impacted constantly by changing relationships with neighboring nation-states or provinces, and increasingly by global impacts that find their way even to remote borderlands of China and Southeast Asia. 
ZHIDING HU is professor of geography at East China Normal University in Shanghai. He is Dean, Department of Regional Geography, and a doctoral supervisor. Dr. Hu received his PhD from Beijing Normal University in 2013. His current research interests are border studies and political geography. He has directed 10 national or provincial research projects and published over 80 academic papers in China and abroad. Email: huzhiding2007@126.com

VICTOR KONRAD teaches geography at Carleton University in Ottawa, Canada. He is author of more than 100 publications in cultural geography, border studies, and Canadian studies, including Beyond Walls: Reinventing the Canada-United States Borderlands (2008). North American Borders in Comparative Perspective will be published in 2020, and Culture, Borders in Globalization, and Canada's Borders will be published in 2021. Professor Konrad is former president of the Association of Borderlands Studies and the Association for Canadian Studies in the United States, and recipient of the Donner Medal. In recent years he has been visiting professor at universities in China, the United States, Finland, and the Netherlands. Email: victor.konrad@cunet.carleton.ca

\section{REFERENCES}

Agamben, G. (2005). State of exception. (K. Attel, Trans.). Palo Alto, CA: Stanford University Press.

Appadurai, A. (1996). Modernity at large: Cultural dimensions of globalization. Minneapolis: University of Minnesota Press.

Baird, I.G., \& Li, C. (2017). Variegated borderlands governance: Examples from Dehong Dai-Jingpo Autonomous Prefecture along the China-Myanmar border. Geoforum 85, 214-224. https://doi.org/10.1016/j.geoforum.2017.07.026.

Baird, I.G., \& Vue, P. (2017). The ties that bind: The role of Hmong social networks in developing small-scale rubber cultivation in Laos. Mobilities 12(1), 136-154. https://doi.org/10.1080/17450101.2015.1016821.

Boyce, G.A. (2018). Appearing "out of place": Automobility and the everyday policing threat and suspicion on the US/Canada frontier. Political Geography 64(May): 1-12. https://doi.org/10.1016/j.polgeo.2018.02.001.

Casaglia, A. (2019). Northern Cyprus as an "inner neighbour": A critical analysis of European Union engagement in Cyprus. European Urban and Regional Studies 26(1): 37-49. https://doi.org/10.1177/0969776418756933.

Coman, R. (2019). Values and power conflicts in framing borders and borderlands: The 2013 reform of EU Shengen governance. Journal of Borderlands Studies 34(5), 685-698. https://doi.org/10.1080/08865655.2017.1402201.

Deleixhe, M., Dembinska, M., \& Iglesias, J.D. (2019). Securitized borderlands. Journal of Borderlands Studies 34(5), 639-647. https://doi.org/10.1080/088865655.20 18.1445547.

Diana, A. (2013). The experimental governing of mobility and trade on the ChinaLaos frontier: The Tai Lue case. Singapore Journal of Tropical Geography 34(1), 25-39. https://doi.org/10.1111/sjtg.12011. 
Freeman, C., \& Thompson, D. (2011). China on the edge. www.cftni.org/china-onthe-edge-april_2011.pdf.

Fox, J. (2009). Crossing borders, changing landscapes: land use dynamics in the Golden Triangle. Asia Pacific Issues 92(December), 1-8.

Holzinger, K., \& Schimmelfennig, F. (2012). Differentiated integration in the European Union: Many concepts, sparse theory, few data. Journal of European Public Policy 19(2), 292-305. https://doi.org/10.1080/13501763.2012.641747.

$\mathrm{Hu}, \mathrm{Z}$., \& Konrad, V. (2018). In the space between exception and integration: The Kokang borderlands on the periphery of China and Myanmar. Geopolitics 23(1), 147-179. https://doi.org/10.1080/14650045.2017.1306777.

Konrad, V. (2015). Toward a theory of borders in motion. Journal of Borderlands Studies 30(1), 1-18. https://doi.org/10.1080/08865655.2015.1008387.

Konrad, V., \& Brunet-Jailly, E. (2019). Approaching borders, creating borderland spaces, and exploring the evolving borders between Canada and the United States. The Canadian Geographer / Le geographecanadien 63(1), 4-10. https://doi .org/10.1111/cag.12515.

Ksoll, C., \& Quarmby, J. (2013). Private sector views on road transport along the Yangon-Manadaly-Muse/Ruili-Kunming corridor. Gms-cbta.org/uploads/ resources/15/attachment/Private_Sector_Views_on_Road_Transport_in_ Myanmar.

Lagerqvist, Y.F. (2013). Imagining the borderlands: Contending stories of a resource frontier in Muang Sing.Singapore Journal of Tropical Geography 34(1), 57-69. https://doi.org/10.1111/sjtg.12013.

Masviriyakul, S. (2004). Sino-Thai strategic economic development in the greater Mekong Region (1992-2003). Contemporary Southeast Asia 26(2), 302-319. https://www.jstor.org/stable/25798690.

Megoran, N. (2017). Nationalism in Central Asia: A biography of the UzbekistanKyrgystan boundary. Pittsburgh, PA: University of Pittsburgh Press.

Mela, A., \& Toldo, A. (2019). Differences, spaces and exclusion. New York: Springer.

Murton, G. (2019). Facing the Fence: The production and performance of a Himalayan border in global contexts. Political Geography 72(June), 31-42. https://doi .org/10.1016/j.polgeo.2019.03.001.

Nyiri, P. (2012). Enclaves of improvement: Sovereignty and developmentalism in the special zones of the China-Lao borderlands. Comparative Studies in Society and History 54(3), 533-562. https://doi.org/10.1017/S0010417512000229.

Pallister-Wilkins, P. (2017). The tensions of the Ceuta and Melilla border fences. In P. Gaibazzi, S. Dunnwald, \& A. Bellagamba (Eds.), EurAfrican borders and migration management (pp. 63-81). New York: Palgrave Macmillan.

Ptak, T., \& Hommel, D. (2016). The trans-political nature of Southwest China's energy conduit, Yunnan Province. Geopolitics 21(3), 556-578. https://doi.org/ 10.1080/14650045.2015.1114471.

Ptak, T., Laine, J., Hu, Z., Konrad, V., Liu, Y., \& van der Velde, M. (2020). Understanding borders through dynamic processes: Capturing relational motion from Southwest China's Radiation Center, Yunnan Province. In Territory, politics, governance (in press). https://doi.org/10.1080/21622671.2020.1764861. 
Ramutsindela, M. (2017). Greening Africa's borderlands: The symbiotic politics of land and borders in peace parks. Political Geography 56(January), 106-113. https://doi.org/10.1016/polgeo.2016.11.012.

Rouviere, L. (2019). Entre souverainete indigene et securite nationale: Negocier la securite frontaliere et la cultura Mohawk a Akweasne. The Canadian Geographer / Le geographecanadien 63(1), 57-68. https://doi.org/10.1111/cag.12497.

Sturgeon, J.C. (2013). Cross-border rubber cultivation between China and Laos: Regionalization by Akha and Tai rubber farmers. Singapore Journal of Tropical Geography 34(1), 70-85. https://doi.org/10.1111/sjtg.12014.

$\mathrm{Su}$, X. (2013). From Frontier to Bridgehead: Cross-border regions and the experience of Yunnan, China. International Journal of Urban and Regional Research 37(4), 1213-1232. https://doi.org/10.1111/j.1468-2427.2012.01191.

$\mathrm{Su}, \mathrm{X}$. (2015). Nontraditional security and China's transnational narcotics control in northern Laos and Myanmar. Political Geography 48(September), 72-82. https://doi.org/10.1016/jpolgeo.2015.06.005.

$\mathrm{Su}, \mathrm{X}$. (2016). Repositioning Yunnan: Security and China's geoeconomic engagement with Mynamar. Area Development and Policy 1(2), 178-194. https://doi .org/10.1080/23792949.2016.1197780.

Summers, T. (2013). Yunnan-A Chinese Bridgehead to Asia: A case study of China's political and economic relations. Cambridge: Chandos-Elsevier.

Teng, L., Zhang, Z., Du, Q., \& Ma, Y. (2017). Regional customs collaboration development strategy in the background of the Belt and Road initiative. In 2017 World Conference on Management Science and Human Social Development (MSHSD 2017). Atlantis Press.

Wang, Y., Kusakabe, K., Lund, R., Panda, S.M., \& Zhao, K. (2013). Mobile livelihoods among ethnic minorities in China: Insights from Yunnan, Norwegian Journal of Geography 67(4), 187-199. https://doi.org/10.1080/00291951.2013.823 238.

Zhou, C. (2012). From Yiwu to Menghai: Yunnan border town on the ancient Tea Travel Road. Urban China 55, 54-55.

\section{Reposicionamiento de espacios de seguridad de exclusión, excepción e integración en fronteras China-Sudeste Asiático}

\section{Zhiding Hu, Victor Konrad}

Resumen: La anteriormente restringida interacción fronteriza ChinaSudeste Asiático, cambió a un extenso compromiso de fronteras reguladas con una jerarquía de cruces y zonas transfronterizas expansivas. Este sistema ampliado de seguridad, revela la infraestructura y prácticas transfronterizas reescaladas y reubicadas como puntos y sistemas de corredores con cruces de vanguardia en Hekou, Mohan y Ruili. Los cambios se enfocan en los cruces primarios y extensión de fronteras, disminuyendo la atención a los cruces menores - después de la implementación de puntos de control de seguridad-, la seguridad móvil y el compro- 
miso a una gestión fronteriza eficaz. Estas zonas permiten la redistribución espacial de la seguridad acomodando los intensificados flujos transfronterizos de personas, bienes e información, conformando espacios de exclusión e integración, así como lugares de excepción focalizados.

Palabras clave: cruces de vanguardia, estrategia de puntos de control, fronteras emergentes, sistema de puntos-corredores

\section{Repositionner les espaces sécuritaires d'exclusion, d'exception et d'intégration dans les zones frontalières entre la Chine et l'Asie du Sud-Est}

\section{Zhiding Hu \& Victor Konrad}

Résumé: L'interaction frontalière entre la Chine et l'Asie du Sud-Est, autrefois localisée et limitée, s'est transformée en un engagement transfrontalier réglementé avec une hiérarchie de passages et des zones frontalières étendues. Ce système de sécurité élargi révèle une infrastructure et une pratique de sécurité frontalière redimensionnées et repositionnées dans un système de points et de corridors avec des passages d'avant-garde à Hekou, Mohan et Ruili. Les changements fondamentaux se concentrent sur les principaux points de passage, les zones frontalières étendues, la mise en œuvre de points de contrôle de sécurité, la sécurité mobile et le compromis, pour permettre une gestion efficace des zones frontalières étendues. Ces dernières permettent la médiation de l'espace et la réaffectation spatiale de la sécurité afin d'accueillir des flux transfrontaliers de personnes, de biens et d'informations considérablement accrus, façonnant ainsi de vastes espaces d'exclusion et d'intégration et des lieux d'exception ciblés.

Mots clés : passages d'avant-garde, sécurité frontalière, zones frontalières émergentes et étendues 